\title{
Genome-wide association with select biomarker traits in the
} Framingham Heart Study

Emelia J Benjamin*1,2,3,4, Josée Dupuis ${ }^{1,4}$, Martin G Larson ${ }^{1,5}$, Kathryn L Lunetta ${ }^{1,4}$, Sarah L Booth ${ }^{6}$, Diddahally R Govindaraju ${ }^{1,2}$, Sekar Kathiresan7,8, John F Keaney Jr2,3, Michelle J Keyes ${ }^{1,5}$, Jing-Ping Lin ${ }^{10,}$ James B Meigs ${ }^{9}$, Sander J Robins ${ }^{1,2}$, Jian Rong ${ }^{1,4}$, Renate Schnabel ${ }^{1,2}$, Joseph A Vita ${ }^{2,3}$, Thomas J Wang8, Peter WF Wilson ${ }^{11}$, Philip A Wolf1,2 and Ramachandran S Vasan 1,2,3

Address: ${ }^{1}$ The National Heart Lung and Blood Institute's Framingham Heart Study, Framingham, MA, USA, ${ }^{2}$ School of Medicine, Boston University, Boston, MA, USA, ${ }^{3}$ Whitaker Cardiovascular Institute, Boston University, Boston, MA, USA, ${ }^{4}$ School of Public Health, Boston University, Boston, MA, USA, ${ }^{5}$ Department of Mathematics and Statistics, Boston, MA, USA, ${ }^{6}$ Jean Mayer USDA Human Nutrition Research Center on Aging, Tufts University, Boston, MA, USA, ${ }^{7}$ Broad Institute of Massachusetts Institute of Technology, Cambridge, MA, USA, ${ }^{8}$ Cardiology Division, Massachusetts General Hospital, Harvard Medical School, Harvard University, Boston, MA, USA, ${ }^{9}$ Department of Medicine, Massachusetts General Hospital, Harvard Medical School, Harvard University, Boston, MA, USA, ${ }^{10}$ Office of Biostatistics Research, National Heart, Lung, and Blood Institute, National Institutes of Health, Bethesda, MD, USA and ${ }^{11}$ Emory School of Medicine, Atlanta, GA, USA

Email: Emelia J Benjamin* - emelia@bu.edu; Josée Dupuis - dupuis@bu.edu; Martin G Larson - mlarson@bu.edu; Kathryn L Lunetta - klunetta@bu.edu; Sarah L Booth - sarah.booth@tufts.edu; Diddahally R Govindaraju - drgraju@bu.edu; Sekar Kathiresan - SKATHIRESAN1@PARTNERS.ORG; John F Keaney - jkeaney@bu.edu; Michelle J Keyes - mjkeyes@bu.edu; JingPing Lin - linj@nhlbi.nih.gov; James B Meigs - jmeigs@partners.org; Sander J Robins - sjrobins@bu.edu; Jian Rong - jrong@bu.edu; Renate Schnabel - schnabel@bu.edu; Joseph A Vita - jvita@bu.edu; Thomas J Wang - tjwang@partners.org; Peter WF Wilson - pwwilso@emory.edu; Philip A Wolf - pawolf@bu.edu; Ramachandran S Vasan - vasan@bu.edu

* Corresponding author

Published: 19 September 2007

BMC Medical Genetics 2007, 8(Suppl I):SII doi:I0.II86/I47I-2350-8-SI-SI I

This article is available from: http://www.biomedcentral.com/I47I-2350/8/SI/SI I

(C) 2007 Benjamin et al; licensee BioMed Central Ltd.

This is an open access article distributed under the terms of the Creative Commons Attribution License (http://creativecommons.org/licenses/by/2.0), which permits unrestricted use, distribution, and reproduction in any medium, provided the original work is properly cited.

\begin{abstract}
Background: Systemic biomarkers provide insights into disease pathogenesis, diagnosis, and risk stratification. Many systemic biomarker concentrations are heritable phenotypes. Genome-wide association studies (GWAS) provide mechanisms to investigate the genetic contributions to biomarker variability unconstrained by current knowledge of physiological relations.
\end{abstract}

Methods: We examined the association of Affymetrix 100K GeneChip single nucleotide polymorphisms (SNPs) to 22 systemic biomarker concentrations in 4 biological domains: inflammation/oxidative stress; natriuretic peptides; liver function; and vitamins. Related members of the Framingham Offspring cohort ( $\mathrm{n}=10 \mathrm{I} 2$; mean age $59 \pm 10$ years, $5 \mathrm{I} \%$ women) had both phenotype and genotype data (minimum-maximum per phenotype $n=507-1008$ ). We used Generalized Estimating Equations (GEE), Family Based Association Tests (FBAT) and variance components linkage to relate SNPs to multivariable-adjusted biomarker residuals. Autosomal SNPs $(n=70,987)$ meeting the following criteria were studied: minor allele frequency $\geq 10 \%$, call rate $\geq 80 \%$ and Hardy-Weinberg equilibrium $p \geq 0.00 \mathrm{I}$.

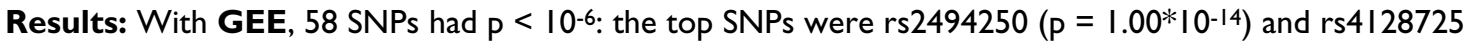

$\left(p=3.68 * 10^{-12}\right)$ for monocyte chemoattractant protein-I (MCPI), and rs2794520 $\left(p=2.83 * 10^{-8}\right)$ and $r s 2808629(p=$ $\left.3.19 * 10^{-8}\right)$ for C-reactive protein (CRP) averaged from 3 examinations (over about 20 years). With FBAT, II SNPs had 
$\mathrm{p}<10^{-6}$ : the top SNPs were the same for MCPI ( $r$ 4128725, $\mathrm{p}=3.28^{*} 10^{-8}$, and $\mathrm{rs} 2494250, \mathrm{p}=3.55^{*} 10^{-8}$ ), and also included B-type natriuretic peptide ( $\mathrm{rs} 43702 \mathrm{I}, \mathrm{P}=\mathrm{I} .0 \mathrm{I}^{*} \mathrm{I} \mathrm{0}^{-6}$ ) and Vitamin $\mathrm{K}$ percent undercarboxylated osteocalcin $\left(r s 2052028, p=1.07^{*} 10^{-6}\right)$. The peak LOD (logarithm of the odds) scores were for MCPI $(4.38$, chromosome I) and CRP (3.28, chromosome I; previously described) concentrations; of note the I.5 support interval included the MCPI and CRP SNPs reported above (GEE model). Previous candidate SNP associations with circulating CRP concentrations were replicated at $P<0.05$; the SNPs rs2794520 and rs2808629 are in linkage disequilibrium with previously reported SNPs. GEE, FBAT and linkage results are posted at http://www.ncbi.nlm.nih.gov/projects/gap/cgi-bin/ study.cgi?id=phs000007.

Conclusion: The Framingham GWAS represents a resource to describe potentially novel genetic influences on systemic biomarker variability. The newly described associations will need to be replicated in other studies.

\section{Background}

There is intense clinical and research interest in blood and urinary biomarkers to diagnose disease, to risk stratify individuals for prognosis and potential intervention, and to provide insights into disease pathogenesis [1]. Hence, it has been proposed that biomarkers may prove useful in the goal of developing what has been referred to as "predictive, preemptive, personalized medicine" [2].

In the present analysis, we examined biomarkers involving four biological systems: inflammation, natriuretic peptides, hepatic function, and vitamins. Circulating inflammatory, natriuretic peptides [3-5], hepatic function $[6,7]$ and vitamin $[8]$ biomarker concentrations have been linked to increased risk of cardiovascular disease and mortality. For instance, the inflammatory marker C-reactive protein (CRP) predicts incident stroke [9], coronary heart disease [10-12], and all-cause mortality [13].

Because of their prognostic importance, there has been interest in understanding the environmental and genetic factors contributing to interindividual variability in systemic biomarker concentrations. Prior reports support the heritability of systemic biomarker concentrations reflecting inflammatory processes $[14,15]$, natriuretic peptides activation [16], hepatic function $[17,18]$, and vitamin metabolism [19]. The majority of prior studies examining the genetic contribution to biomarker concentrations have examined genetic linkage or variation in selected candidate genes. Although there have been some successes with both approaches [20], the specific genes contributing to variability of most circulating biomarkers are incompletely understood. We examined the relation of single nucleotide polymorphisms (SNPs) on the Affymetrix $100 \mathrm{~K}$ chip to variation in systemic biomarker concentrations. The GWAS approach has the advantage that it is not constrained by known physiologic associations.

\section{Materials and methods Study sample}

The biomarkers were assessed in the Framingham Offspring sample, which is described in the Framingham
100K Overview [21]. Briefly, the Framingham Offspring were recruited in 1971-1974 from the children (and children's spouses) of the Framingham Original Cohort [22]. The examinations and the number of participants in which the biomarkers were assessed vary by analyte, as noted in Table 1.

\section{Phenotype definitions and methods}

Biomarkers were measured on morning specimens after an overnight fast (typically 10 hours) between 7:30 and 9:00 am. EDTA and citrated blood collection tubes are centrifuged in a refrigerated centrifuge immediately after venipuncture. Serum blood collection tubes sit for 30 minutes after venipuncture to allow for complete clotting. Specimens are processed immediately after centrifugation. Blood samples were centrifuged and frozen at $-20^{\circ}$ (examination 2 through 4 ) and $-80^{\circ}$ (examinations 5 through 7). The measurement of the inflammatory markers is detailed in the inflammatory marker manual at the National Center for Biotechnology Information http:// www.ncbi.nlm.nih.gov/projects/gap/cgi-bin/ study.cgi?id=phs000007.

Inflammatory biomarkers (except CRP) were measured in duplicate with commercially available ELISA kits: R\&D Systems (intercellular adhesion molecule-1, interleukin6, monocyte chemoattractant-1 [MCP1], P-selectin, tumor necrosis factor receptor 2, high sensitivity tumor necrosis factor- $\alpha$ ), Bender MedSystems (CD40 ligand), Oxis (myeloperoxidase), and BIOMEDICA (osteoprotegerin). High-sensitivity CRP was measured in 2002 and 2004 on examination cycle 2, 6 and 7 specimens with a Dade Behring nephelometer; the less sensitive Hemagen assay was used in 1998 for examination cycle 5 specimens. Natriuretic peptides were measured by Shionogi using a noncompetitive high sensitivity immunoradiometric assay [23]. Liver function tests were measured at examination cycle 2 by Quest Diagnostics (previously METPATH) with a variety of methods: $\gamma$-glutamyl aminotransferase was measured with spectrophotometry [7], bilirubin was measured by the colorimetric method (Dow Bilirubin Kit) [24,25]; alkaline phosphatase was meas- 
Table I: Types of traits phenotype master trait table, exam cycle, numbers of participants in family plates with phenotype

\begin{tabular}{|c|c|c|c|c|c|}
\hline Phenotype & Acronym & Trait $\mathbf{N}=27 *$ & Subject $\mathbf{N}$ & Offspring Exam & Adjustment* Multivariable model \\
\hline \multicolumn{6}{|c|}{ Inflammation/Oxidative Stress } \\
\hline CD40 Ligand, serum \& plasma & CD40L & 2 & 998 & 7 & $\begin{array}{l}\text { Age, sex, smoking, systolic and } \\
\text { diastolic blood pressure, hypertension } \\
\text { treatment, body mass index, waist } \\
\text { circumference, Total/HDL cholesterol, } \\
\text { triglyceride, lipid lowering medication, } \\
\text { glucose, diabetes, aspirin, hormone } \\
\text { replacement therapy and prevalent } \\
\text { cardiovascular disease }\end{array}$ \\
\hline C-reactive protein & CRP & 5 & $980-1008$ & $2,5,6,7 ;$ Average: $2,6,7$ & \\
\hline Intercellular adhesion molecule-I & ICAMI & 1 & 1006 & 7 & \\
\hline Interleukin-6 & IL6 & 1 & 1006 & & \\
\hline Urinary isoprostanes/creatinine & IsoCrUrine & 1 & 828 & & \\
\hline Monocyte chemoattractant protein-I & $\mathrm{MCPI}$ & 1 & 989 & & \\
\hline Myeloperoxidase & MPO & 1 & 974 & & \\
\hline Osteoprotegerin & OPG & 1 & 1005 & & \\
\hline P-selectin & Pselectin & 1 & 1007 & & \\
\hline Tumor necrosis factor alpha & TNFA & i & 753 & & \\
\hline Tumor necrosis factor receptor- 2 & TNFRII & 1 & 980 & & \\
\hline
\end{tabular}

Natriuretic Peptides

\begin{tabular}{|c|c|c|c|c|c|}
\hline $\mathrm{N}$-terminal pro-atrial natriuretic peptide & ANP & I & 938 & 6 & $\begin{array}{l}\text { Age, sex, BMI, SBP, HTN Rx, LDL } \\
\text { Total/HDL, diabetes, LV mass, LA size, } \\
\text { CVD }\end{array}$ \\
\hline B-type natriuretic peptide & BNP & I & 938 & & \\
\hline
\end{tabular}

Liver Function

\begin{tabular}{|c|c|c|c|c|c|}
\hline Bilirubin & Bili & 1 & 910 & 2 & $\begin{array}{l}\text { Age, sex, BMI, HDL, HTN, diabetes, } \\
\text { serum total protein, alcohol intake, } \\
\text { TG, \& smoking }\end{array}$ \\
\hline Aspartate aminotransferase $* *$ & AST & I & 904 & & \\
\hline Alanine aminotransferase & $\mathrm{ALT}$ & 1 & 904 & & \\
\hline Alkaline phosphatase & AlkPhos & I & 904 & & \\
\hline Gamma-glutamyl transferase & GGT & I & 896 & & \\
\hline
\end{tabular}

\begin{tabular}{|c|c|c|c|c|c|}
\hline \multicolumn{6}{|c|}{ Vitamins } \\
\hline Vitamin K plasma phylloquinone & VitKPhylloq & I & 518 & $6 / 7 \dagger$ & $\begin{array}{l}\text { Age, sex, SBP, DBP, BMI, waist, total/ } \\
\text { HDL, smoking, glucose, TG, diabetes, } \\
\text { HTN Rx, lipid lowering Rx, hormone } \\
\text { replacement Rx, asthma Rx, alcohol } \\
\text { use, prevalent CVD }\end{array}$ \\
\hline Vitamin $\mathrm{K}$ percentage of undercarboxylated osteocalcin & VitKPucOC & I & 504 & & \\
\hline Vitamin D plasma $25(\mathrm{OH})-\mathrm{D}$ & VitD25OH & I & 517 & & \\
\hline
\end{tabular}

*Each trait had 2 adjustment schemes web posted: age- and sex-adjusted, and multivariable-adjusted at http://www.ncbi.nlm.nih.gov/projects/gap/cgi-bin/ study.cgi?id=phs000007. GEE and FBAT traits are web displayed pha001 II 5 through pha0012 I8; Linkage traits are located from pha00230I through pha002352. In the present manuscript we examine the multivariable-adjusted trait, which we count as I trait. Note: biomarkers were natural log transformed due to skewed distribution; **normalized deviates. †Vitamin measurements straddled exams 6 \& 7, covariates from same exam biomarker assayed. SBP, DBP = systolic and diastolic blood pressure, $\mathrm{HTN} \mathrm{Rx}=$ hypertension treatment, $\mathrm{BMI}=$ body mass index, $\mathrm{TC} / \mathrm{HDL}=$ total/high density lipoprotein cholesterol; $\mathrm{TG}=$ triglyceride, $\mathrm{HRT}=\mathrm{hormone}$ replacement therapy, Rx = medication therapy, CVD = cardiovascular disease; LDL = low density lipoprotein; LV mass = left ventricular mass; LA size = left atrial size; Atrial natriuretic peptide $=\mathrm{N}$-terminal pro-atrial natriuretic peptide.

ured with the kinetic method [26,27]; aspartate aminotransferase and alanine aminotransferase were measured using the kinetic method with Beckman LiquidStat Reagent Kit [28]. Vitamin K status was measured as phylloquinone concentrations with reverse phase highperformance liquid chromatography [29], and percentage of undercarboxylated osteocalcin was measured by radioimmunoassay [30,31], Vitamin D status was measured as
25(OH)D concentrations by using RIA (DiaSorin, Stillwater MN).

Plasma samples were used for natriuretic peptides, vitamin $\mathrm{K}$ phylloquinone, vitamin $\mathrm{D}$, and some inflammatory markers including CD40 ligand, osteoprotegerin, Pselectin, tumor necrosis factor receptor 2, and tumor necrosis factor- $\alpha$. Serum samples were analyzed for liver 
function, vitamin $\mathrm{K}, \%$ undercarboxylated osteocalcin, and other inflammatory markers including CRP, interleukin-6, soluble intracellular adhesion molecule-1, MCP1, and myeloperoxidase concentrations. The reproducibility of the biomarkers was good; the intra-assay coefficients of variation were CD40 ligand 4.4\%, interleukin-6 3.1\%, intercellular adhesion molecule-1 3.1\%, MCP1 4.1\%, myeloperoxidase $3.0 \%$, osteoprotegerin $3.7 \%$, P-selectin 3.0\%, tumor necrosis factor- $\alpha 8.8 \%$, and tumor necrosis factor receptor-2 2.3\%; the inter-assay coefficients of variation were brain natriuretic peptide $12.2 \%$, n-terminal-atrial natriuretic peptide $12.7 \%$. The Kappa statistic for 146 CRP samples run in duplicate was 0.95 [32]. Coefficients of variation for aspartate aminotransferase and alanine aminotransferase, respectively, were 10.7 and $8.3 \%$. The coefficients of variation for low and high Vitamin K plasma phylloquinone concentrations were 15.2 and $10.9 \%$ respectively on control specimens. For low, medium and high osteocalcin concentrations used to determine Vitamin K percentage of undercarboxylated osteocalcin, the coefficients of variation were $22.3,12.8$, and $7.8 \%$, respectively. For Vitamin $\mathrm{D}$, the coefficients of variation were $8.5 \%$ and $13.2 \%$, respectively.

\section{Genotyping methods}

Details of the genotyping methods are available in the Framingham Heart Study 100K Overview [21]. Framingham staff extracted genomic DNA with a Qiagen Blood and Cell Culture Maxi Kit from immortalized lymphoblasts. Briefly, SNPs on the Affymetrix $100 \mathrm{~K}$ chip were genotyped ( $\mathrm{n}=112,990$ autosomal SNPs) in a sample of family members of the Original and Offspring cohorts of the Framingham Heart Study [33]. SNPs were excluded for the following reasons: minor allele frequency $<10 \% \mathrm{n}=$ 38062; call rate $<80 \% \mathrm{n}=2346$; Hardy-Weinberg equilibrium $\mathrm{p}$-value $<0.001 \mathrm{n}=1595$, leaving 70,987 SNPs available for analysis.

\section{Statistical analysis methods}

We created standardized multivariable-adjusted natural log transformed biomarker residuals adjusted for the covariates listed in Table 1. The CRP average residuals were constructed as follows: (1) create age- and sex-adjusted or multivariable-adjusted residual at each of exams 2, 6 and 7; (2) take average of the residuals across exams; (3) the residual was excluded if there were not at least 2 exams for its calculation. In some instances we performed additional transformation (e.g. Winsorized models). Tobit models were used to generate residuals for the natriuretic peptides, because $2 \%$ of N-ANP levels and $30 \%$ of BNP levels were below the respective assay detection limits. Association and linkage results examining age- and sexadjusted residuals are posted at the web site. As described in the Overview [21], we examined generalized estimating equations (GEE) and family based association testing (FBAT), assuming an additive genetic effect, to account for correlation among related individuals within nuclear families. We also used Merlin software [34] (splitting the largest families) to compute exact identity by descent linkage, with variance component analysis in SOLAR using 11,200 SNPs and short tandem repeats [35]. Traits with extreme values, as defined by 4 standard deviations away from the mean, were Winsorized at 4.0 in secondary linkage analyses to determine the sensitivity of the logarithm of the odds (LOD) score to the presence of outlier values.

\section{Results}

Twenty-two biomarker traits (plus 4 additional CRP traits) were analyzed in 1012 Offspring participants, on log-transformed multivariable-adjusted residuals as outlined in Table 1 (minimum-maximum per phenotype $\mathrm{n}=$ 507-1008). The phenotypes were collected at various Framingham Offspring examinations from cycles 2 to 7 . At examination cycles 2 and 7 the mean age of the participants with both phenotype and genotype data was $41 \pm$ 10 and $59 \pm 10$ years, and $51.2 \%$ and $51.1 \%$ were women, respectively. For details of biomarker phenotype-genotype association refer to http://www.ncbi.nlm.nih.gov/ projects/gap/cgi-bin/study.cgi?id=phs000007.

There were 58 SNPs associated with biomarker concentrations with a $\mathrm{p}<10^{-6}$ by GEE. The 25 most statistically significant GEE associations sorted by p-value, listed with their corresponding FBAT p-value are shown in Table $2 \mathrm{a}$. MCP1 concentrations were associated with rs2494250 (p $\left.=1^{*} 10^{-14}\right)$ and $\operatorname{rs} 4128725\left(\mathrm{p}=3.68^{*} 10^{-12}\right)$, both on chromosome 1, near the FCER1A and the OR10J1 genes, respectively. CRP concentrations averaged over 3 examinations (about 20 years) were associated with rs 2794520 $\left(\mathrm{p}=2.83^{*} 10^{-8}\right)$ and $\mathrm{rs} 2808629\left(\mathrm{p}=3.19^{*} 10^{-8}\right)$.

We estimated the amount of variability in biomarker concentrations explained by the 4 most statistically significant SNPs in the GEE model using a pseudo measure of $\mathrm{R}^{2}$ based on log-likelihood estimates [36]. The two most statistically significant GEE SNPs explained about 7\% and $4 \%$ of the variability in MCP1 concentrations $\left(\mathrm{R}^{2}=0.070\right.$ for rs 2494250 and $R^{2}=0.043$ for rs4128725); for CRP concentrations averaged over examinations 2, 6, and 7 the two most statistically significant GEE SNPs explained $2.3 \%$ of the variability $\left[\mathrm{R}^{2}=0.023\right.$ for $\mathrm{rs} 2794520$ and rs2808629) [36]. We also examined the linkage disequilibrium between the most statistically significant GEE SNPs: rs2494250 and rs4128725 had a D' $=0.724$ and an $r^{2}=0.196$, whereas rs2794520 and rs2808629 served as perfect proxies for each other $\left(D^{\prime}=1 ; r^{2}=1\right)$.

With FBAT, 11 SNPs were associated with biomarker concentrations with a $\mathrm{p}<10^{-6}$. The two most statistically sig- 
Table 2: Top genetic associations with biomarkers based on the lowest p value for GEE test (2a), FBAT (2b), and Linkage (2c)

2a. Top 25 associations with biomarkers based on the lowest $p$ value of the GEE test

\begin{tabular}{|c|c|c|c|c|c|c|}
\hline Trait & SNP rs ID* & Chr & Physical location (bp) & GEE P-value & FBAT P-value & IN/NEAR gene \\
\hline Monocyte chemoattractant protein-I & rs2494250 & 1 & $15609 \mid 324$ & $1.0 * 10^{-14}$ & $3.5^{*} 10^{-8}$ & FCERIA, ORIOJ3 \\
\hline Monocyte chemoattractant protein-I & rs4128725 & 1 & 156219032 & $3.7 * 10^{-12}$ & $3.3 * 10^{-8}$ & ORIOJI \\
\hline C-reactive protein average exams $2,6,7$ & rs2794520 & 1 & 156491889 & $2.8 * 10-8$ & $4.3^{*} 10^{-5}$ & $C R P$ \\
\hline C-reactive protein average exams $2,6,7$ & rs2808629 & 1 & 156489869 & $3.2 * 10^{-8}$ & $4.8^{*} 10^{-5}$ & $C R P$ \\
\hline C-reactive protein exam 6 & rs2794520 & 1 & 156491889 & $1.3 * 10^{-7}$ & $3.9 * 10^{-4}$ & $C R P$ \\
\hline C-reactive protein exam 6 & rs2808629 & 1 & 156489869 & $1.4 * 10-7$ & $4.3^{*} 10^{-4}$ & $C R P$ \\
\hline Tumor necrosis factor alpha & rs7552393 & 1 & 83966572 & $5.1 * 10^{-7}$ & 0.63 & \\
\hline C-reactive protein exam 6 & rs74696I & 19 & 35791730 & $7.5 * 10^{-7}$ & 0.03 & ZNF536 \\
\hline Bilirubin & rs 17532515 & 4 & 141745043 & $1.0 * 10-6$ & $9.2^{*} 10^{-6}$ & CLGN, ELMOD2 \\
\hline Alanine aminotransferase & rs1998303 & 9 & 82644535 & $1.1 * 10^{-6}$ & 0.005 & \\
\hline Monocyte chemoattractant protein-I & rs10489849 & 1 & 156009838 & $1.1 * 10^{-6}$ & 0.10 & IGSF4B \\
\hline Alkaline phosphatase & rs 10518765 & 15 & 52467924 & $1.1 * 10^{-6}$ & $1.7^{* 10^{-4}}$ & \\
\hline Vitamin K plasma phylloquinone & rs2387326 & 10 & 129823446 & $1.1 * 10^{-6}$ & 0.02 & PTPRE, MKI67 \\
\hline C-reactive protein average exams $2,6,7$ & rsIII9582 & 5 & 125270919 & $1.2 * 10-6$ & $4.2 * 10^{-4}$ & \\
\hline Vitamin D plasma $25(\mathrm{OH})-\mathrm{D}$ & rs 10485165 & 6 & 89169536 & $1.4 * 10^{-6}$ & 0.003 & \\
\hline Atrial natriuretic peptide exam 6 & rs1417352 & 6 & 107005919 & $1.8 * 10^{-6}$ & 0.009 & \\
\hline C-reactive protein exam 2 & rs583012 & 10 & 54964880 & $1.9 * 10-6$ & 0.09 & \\
\hline Atrial natriuretic peptide exam 6 & rs 1486139 & 7 & 46048968 & $2.0 * 10^{-6}$ & 0.04 & \\
\hline Atrial natriuretic peptide exam 6 & rs|486|40 & 7 & 46048877 & $2.2 * 10^{-6}$ & 0.06 & \\
\hline Alanine aminotransferase exam 2 & rs1049268I & 13 & 39705483 & $2.2 * 10^{-6}$ & $9.9 * 10^{-5}$ & \\
\hline Vitamin D plasma $25(\mathrm{OH})-\mathrm{D}$ & rs 10507577 & 13 & 52866092 & $2.6 * 10^{-6}$ & 0.004 & \\
\hline Atrial natriuretic peptide exam 6 & rs1079596 & 11 & 112801829 & $2.6 * 10^{-6}$ & 0.03 & DRD2 \\
\hline Monocyte chemoattractant protein-I & rs |474747 & 1 & 155961586 & $2.8 * 10^{-6}$ & $8.7 * 10^{-4}$ & IGSF4B \\
\hline CD40 Ligand serum & rs7778619 & 7 & 9923216 & $3.0 * 10^{-6}$ & 0.19 & \\
\hline CD40 Ligand serum & rs8005745 & 14 & 76473583 & $3.5 * 10^{-6}$ & 0.01 & \\
\hline
\end{tabular}

2b. Top 25 associations with biomarkers based on the lowest $p$ value of the FBAT test

\begin{tabular}{|c|c|c|c|c|c|c|}
\hline Trait & SNP rs ID* & Chr & Physical location (bp) & GEE P-value & FBAT P-value & IN/NEAR gene \\
\hline Monocyte chemoattractant protein-I & rs4I 28725 & 1 & 156219032 & $3.7 * 10^{-12}$ & $3.3 * 10^{-8}$ & ORIOJI \\
\hline Monocyte chemoattractant protein-I & rs2494250 & 1 & 156091324 & $1.0 * 10^{-14}$ & $3.5 * 10^{-8}$ & FCERIA, ORIOJ3 \\
\hline B-type natriuretic peptide & rs43702I & 1 & 61450291 & $1.5 * 10^{-4}$ & $1.0 * 10-6$ & NFIA \\
\hline $\begin{array}{l}\text { Vitamin } \mathrm{K} \% \text { undercarboxylated } \\
\text { osteocalcin }\end{array}$ & rs2052028 & 7 & 15789103 & $5.2 * 10^{-6}$ & $1.1 * 10^{-6}$ & \\
\hline CD40 Ligand plasma & rs2372184 & 3 & 65673194 & 0.003 & $2.5 * 10-6$ & MAGII \\
\hline Urinary isoprostanes/creatinine & rs7|7|45 & 20 & |582609| & 0.003 & $5.0 * 10-6$ & C20orfl 33 \\
\hline CD40 Ligand serum & rs4664604 & 2 & 153398916 & 0.01 & $8.4 * 10^{-6}$ & ARL6IP6 \\
\hline CD40 Ligand serum & rs9288I25 & 2 & 153348619 & 0.01 & $9.1 * 10^{-6}$ & FMNL2, ARL6IP6 \\
\hline C-reactive protein exam 7 & rs|363258 & 5 & 103297593 & 0.02 & $9.2 * 10-6$ & \\
\hline
\end{tabular}


Table 2: Top genetic associations with biomarkers based on the lowest p value for GEE test (2a), FBAT (2b), and Linkage (2c)

\begin{tabular}{|c|c|c|c|c|c|c|}
\hline Bilirubin & rsI75325I5 & 4 & 141745043 & $1.0 * 10-6$ & $9.2 * 10^{-6}$ & CLGN, ELMOD2 \\
\hline Osteoprotegerin & rs496269 & 6 & 79457094 & 0.03 & $9.4 * 10^{-6}$ & \\
\hline C-reactive protein average $2,6,7$ & rsl363258 & 5 & 103297593 & 0.009 & $1.3 * 10-5$ & \\
\hline CD40 Ligand serum & rs303939 & 13 & 71269472 & 0.008 & $1.3 * 10^{-5}$ & $\mathrm{DACHI}$ \\
\hline Myeloperoxidase & rsl0501981 & 11 & 100880825 & $1.1 * 10^{-5}$ & $1.4 * 10^{-5}$ & TRPC6 \\
\hline Urinary isoprostanes/creatinine & rs1461549 & 14 & $24782 \mid 40$ & 0.26 & $1.5 * 10^{-5}$ & \\
\hline Tumor necrosis factor alpha & rs2353803 & 7 & 11060282 & 0.03 & $1.5 * 10^{-5}$ & \\
\hline Intercellular adhesion molecule-I & rs3849944 & 9 & 27550594 & $5.3^{*} 10^{-6}$ & $1.5 * 10-5$ & C9orf72 \\
\hline CD40 Ligand serum & rsl986743 & 2 & $1534 \mid 2407$ & 0.01 & $1.6 * 10^{-5}$ & ARL6IP6 \\
\hline Gamma-glutamyl transferase & rs962976 & 12 & 67006894 & 0.002 & $1.6 * 10^{-5}$ & MDMI \\
\hline C-reactive protein average $2,6,7$ & rs2421608 & 2 & 117013763 & 0.02 & $1.8 * 10-5$ & \\
\hline C-reactive protein exam 2 & rs642245 & 11 & 86067184 & 0.03 & $1.9 * 10^{-5}$ & ME3 \\
\hline Tumor necrosis factor receptor-2 & rs248328 & 5 & $17930969 \mid$ & 0.59 & $1.9 * 10^{-5}$ & $\begin{array}{l}\text { TBCID9B, } \\
\text { RNFI } 30\end{array}$ \\
\hline C-reactive protein exam 7 & rs2390582 & 1 & 90655928 & 0.07 & $2.0 * 10^{-5}$ & \\
\hline Osteoprotegerin & rs9352609 & 6 & 79442188 & 0.04 & $2.0 * 10-5$ & \\
\hline Intercellular adhesion molecule-I & rs7445II & 14 & 39166736 & $3.2 * 10-4$ & $2.1 * 10-5$ & \\
\hline
\end{tabular}

2c. Magnitude and Location of Peak LOD scores > 2.5 for regions in the Biomarker Phenotype Group

\begin{tabular}{|c|c|c|c|c|c|c|c|}
\hline Trait & Exam & Chr & Physical location (bp) & $\underset{\text { LOD }}{\text { Maximum }}$ & $\begin{array}{l}\text { LOD-I.5 } \\
\text { Interval }\end{array}$ & $\begin{array}{l}\text { LOD+1.5 } \\
\text { Interval }\end{array}$ & $\underset{\text { WIN* }}{\text { Maximum LOD }}$ \\
\hline Monocyte chemoattractant protein-I & 7 & I & 159093573 & 4.96 & $15490890 \mid$ & $|5975| 22 \mid$ & 4.38 \\
\hline Monocyte chemoattractant protein-I & 7 & 10 & $|29553| 48$ & 4.03 & 128294406 & 130084334 & 3.23 \\
\hline C-reactive protein & 5 & 1 & 154745847 & 3.53 & 153213133 & $|5656757|$ & 3.28 \\
\hline Monocyte chemoattractant protein-I & 7 & 17 & 13630703 & 3.33 & 10874193 & 16776778 & 2.54 \\
\hline Intercellular adhesion molecule-I & 7 & I & 203535232 & 2.95 & 202207846 & 215367881 & 2.93 \\
\hline Monocyte chemoattractant protein-I & 7 & 7 & 92544810 & 2.94 & 88727093 & 105546050 & 2.01 \\
\hline Tumor necrosis factor receptor 2 & 7 & I & 54001041 & 2.92 & 43070922 & 60590679 & 2.95 \\
\hline Gamma-glutamyl transferase & 2 & 3 & 26424584 & 2.89 & 24621158 & 27418642 & 2.96 \\
\hline B-type natriuretic peptide & 6 & 12 & $4 \mid 40574$ & 2.77 & 132045 & 8137669 & No outliers \\
\hline Gamma-glutamyl transferase & 2 & 10 & $129553 \mid 48$ & 2.67 & 120112006 & 132560638 & 2.79 \\
\hline Vitamin D plasma $25(\mathrm{OH})-\mathrm{D}$ & $6 / 7$ & 8 & 140624328 & 2.67 & 138952328 & $146039 \mid 26$ & 2.68 \\
\hline B-type natriuretic peptide & 6 & 19 & 34016706 & 2.59 & 13425865 & 43186344 & No outliers \\
\hline Myeloperoxidase & 7 & 19 & 11295505 & 2.56 & 3026853 & 16489850 & 2.56 \\
\hline Alkaline phosphatase & 2 & 6 & 170538204 & WIN & 162441307 & 170788550 & 2.55 \\
\hline Osteoprotegerin & 7 & 13 & 75274475 & 2.52 & 71928655 & 81228082 & 2.95 \\
\hline
\end{tabular}

$\mathrm{bp}=$ base pair Chr = chromosome; $\mathrm{WIN}=$ Winsorized.

dbSNP positions are from NCBI Build 35 (hg I7);

LD between rs2494250 and rs4 I 28725 (top MCPI SNPs): $D^{\prime}=0.724$ and $r$ squared $=0.196$.

LD between rs2794520 and rs2808629 (top CRP SNPs): $D^{\prime}=1.0$ and $r$ squared $=1.0$.

$*$ Winsorized LOD scores were run for this manuscript, and are not displayed on the web. 
Table 3: Combined phenotypes

\begin{tabular}{|c|c|c|c|c|c|c|}
\hline Trait & SNP rs ID & Chr & $\begin{array}{r}\text { Physical location } \\
\text { (bp) }\end{array}$ & GEE P-value & FBAT P-value & IN/NEAR gene \\
\hline \multicolumn{7}{|c|}{ 3a. SNPs significant for 3 correlated phenotypes at exam 7 by either GEE or FBAT at $p<0.01$} \\
\hline \multirow[t]{20}{*}{ Interleukin-6, C-reactive protein and Fibrinogen } & rs 10511884 & 9 & 31668988 & $5.7 * 10^{-5}$ & 0.0065 & \\
\hline & rs 1887027 & 10 & 6153788 & $2.6 * 10^{-4}$ & 0.19 & IL2RA, RBMI 7 \\
\hline & rs2831617 & 21 & 28481515 & $6.2 * 10^{-4}$ & 0.0027 & \\
\hline & rs 2831620 & 21 & 28481869 & $6.4^{*} 10^{-4}$ & 0.0022 & \\
\hline & rs 2831618 & 21 & 28481749 & $6.4 * 10^{-4}$ & 0.0020 & \\
\hline & rs204440I & 9 & 31659518 & $6.6 * 10^{-4}$ & 0.12 & \\
\hline & rs 1457590 & 3 & 21530978 & 0.0019 & 0.16 & ZNF659 \\
\hline & rs6848323 & 4 & 113286305 & 0.0022 & 0.14 & \\
\hline & rs3110134 & 8 & 60260538 & 0.0025 & 0.12 & \\
\hline & rs2016740 & 4 & 113238018 & 0.0039 & 0.17 & \\
\hline & rs719006 & 15 & 59210481 & 0.0044 & 0.76 & RORA \\
\hline & rs877936 & 4 & 113238472 & 0.0055 & 0.31 & \\
\hline & rs1436136 & 4 & 113421130 & 0.0062 & 0.039 & \\
\hline & rsl436336 & 3 & 106156256 & 0.0067 & 0.0040 & \\
\hline & rs698270 & 3 & 137592210 & 0.0086 & 0.020 & STAGI \\
\hline & rs847428 & 7 & 16803192 & 0.019 & 0.025 & \\
\hline & rs2359763 & 3 & 23424931 & 0.024 & 0.0025 & \\
\hline & rs7969455 & 12 & 7757402 & 0.059 & 0.0015 & DPPA3 \\
\hline & rs105037I7 & 8 & 22634817 & 0.06 & 0.0028 & \\
\hline & rs4899940 & 14 & 87623621 & 0.11 & 0.0019 & \\
\hline \multicolumn{7}{|c|}{ 3b. Combined phenotypes within a specific biological domain } \\
\hline \multirow[t]{6}{*}{ C-reactive protein: exams $2,5,6,7$} & rs2808629 & 1 & 156489869 & $6.9 * 10^{-5}$ & $4.7 * 10^{-4}$ & NFIA, CRP \\
\hline & rs2794520 & 1 & 156491889 & $6.1 * 10^{-5}$ & $4.85 * 10-4$ & FCERIA, CRP \\
\hline & rs6563212 & 13 & 35380415 & $7.3^{*} 10^{-4}$ & 0.30 & DCAMKLI \\
\hline & rsII 626844 & 14 & 72413330 & $5.1 * 10^{-3}$ & 0.17 & ORIOJI, DPF3 \\
\hline & rs9319160 & 13 & 84918646 & 0.002 & 0.09 & \\
\hline & rs910232 & 1 & 17143820 & 0.002 & 0.01 & MAGII, PADI2 \\
\hline \multirow[t]{2}{*}{ Liver function: Alkaline phosphatase; AST; ALT; GGT } & rs4911146 & 20 & 32103708 & 0.01 & $8.4^{*} 10^{-6}$ & ARL6IP6, RALY \\
\hline & rs953402 & 3 & 5986639 & 0.01 & $9.1 * 10^{-6}$ & FMNL2 \\
\hline $\begin{array}{l}\text { Vitamin D, Vitamin K phylloquinone \& Vitamin K \% } \\
\text { undercarboxylated osteocalcin }\end{array}$ & rs 1376544 & 4 & 180293700 & 0.02 & $9.2 * 10^{-6}$ & \\
\hline
\end{tabular}

Chr = chromosome;

For a given SNP, all of the phenotypes either FBAT or GEE significant if FBAT < 0.01 for particular SNP;

$\mathrm{P}$-values = the geometric mean of the $\mathrm{p}$-value for all traits within the biomarker cluster

nificant SNPs for FBAT were the same two SNPs observed with GEE: MCP1 concentrations were significantly associated with rs4128725, $\mathrm{p}=3.28^{*} 10^{-8}$, and $\mathrm{rs} 2494250, \mathrm{p}=$ $3.55^{*} 10^{-8}$ (Table $2 \mathrm{~b}$ ). In addition, B-type natriuretic peptide (rs437021, $\mathrm{p}=1.01^{*} 10^{-6}$ ) and Vitamin K\% undercarboxylated osteocalcin ( $\mathrm{rs} 2052028, \mathrm{p}=1.07^{*} 10^{-6}$ ) also were nominally statistically significantly associated.

In Table 2c we list the magnitude and location of LOD scores $>2.5$ observed for the circulating biomarker traits. Because we were concerned that some of the LOD scores might be inflated by individuals with extreme marker concentrations, we reanalyzed the LOD scores on Winsorized residuals. The peak Winsorized LOD scores observed were for the biomarkers MCP1 (4.38, chromosome 1), and CRP (3.23, chromosome 10; 3.28, chromosome 1). Of note the 1.5 LOD support intervals for the linkage peaks on chromosome 1 included the SNPs significantly associated with MCP1 and CRP reported above (GEE model).
In an effort to potentially uncover genetic pleiotropy we display in Table 3 two ways to synthesize findings across phenotypes. We examined 3 correlated inflammatory biomarker phenotypes, interleukin-6, CRP and fibrinogen, and report SNPs that were significantly associated with all 3 phenotypes by GEE or FBAT at $\mathrm{p}<0.01$ (Table 3a). We also examined phenotypes within a specific biomarker category including CRP over multiple examinations, liver function tests and vitamin concentrations (nutrients involved in bone health $[37,38]$ ), and display in Table 3b SNPs significant by either FBAT or GEE at a p $<0.01$ for all of the phenotypes in a given phenotype cluster.

In Table 4 we compared our data with previously reported phenotype-genotype associations in the published literature on systemic biomarker concentrations: bilirubin concentrations (TA repeat in UGT1A1) [39,40]; CRP (CRP) [20,32,41-50], intercellular adhesion molecule-1 (ICAM1) [51-54], interleukin-6 (IL6) [55-62], and MCP1 
$(C C L 2=$ MCP1 gene $[63,64])$. Unfortunately, there were no SNPs within $60 \mathrm{~KB}$ of the ICAM1 gene on the Affymetrix $100 \mathrm{~K}$ chip. There was no association between bilirubin concentrations and 1 SNP within $30 \mathrm{~kb}$ (rs741159) + 2 more SNPs within $50 \mathrm{~kb}$ (rs726017 and rs6752792) of a previously reported TA repeat in UGT1A1. Additionally, there was no association between interleukin- 6 concentrations and SNPs in the ILG region despite one SNP in high LD (linkage disequilibrium; $\mathrm{r}^{2}=$ $0.819)$ with the previously reported rs 1800795 (-174G/C) SNP. Similarly, we did not observe an association between MCP1 concentrations and SNPs in the CCL2 region, despite one SNP with a high $\mathrm{r}^{2}(0.956)$ with the SNP previously reported in the literature. For CRP concentrations, we had 2 SNPs in perfect LD with rs1205, and we observed strong evidence for replication. However, it should be noted that this association has been previously reported by Framingham investigators in unrelated participants [32]. Similarly, rs431568, which is in high LD $\left(\mathrm{r}^{2}=\right.$ 0.83 ) with 2 previously associated SNPs (rs3116653 and rs1417938), was highly associated with many of the CRP phenotypes.

\section{Discussion}

In collaboration with NCBI we have web-posted our unfiltered biomarker-genotype associations and linkage results to provide a resource to investigators seeking to understand and replicate their biomarker-genotype associations. We submit that the findings of highest priority for follow-up are associations that were detected by several statistical approaches. MCP1 was associated with 2 SNPs on chromosome 1 (rs4128725 and rs2494250) with pvalues in the $10^{-8}$ by FBAT, $\leq 10^{-12}$ by GEE. Acknowledging that linkage is less powerful and accurate, we note that the 1.5 support interval for the MCP1 linkage peak (Winsorized maximum LOD 4.38) on chromosome 1 supports the GEE and FBAT analyses. Findings for CRP (chromosome 1), brain natriuretic peptide (chromosome 1) and Vitamin K \% undercarboxylated osteocalcin (Chromosome 7) are also of potential priority for follow-up. We acknowledge that the ultimate validation of our findings will require replication in other cohorts and functional studies.

A fundamental challenge of GWAS tests is sorting through associations and prioritizing SNPs for follow-up. In the absence of external replication, one approach to synthesizing findings is to examine associations across similar biological domains, which may capture pleiotropy. We presented the exploratory analyses in Tables $3 \mathrm{a}$ and $3 \mathrm{~b}$, but reiterate that the findings will need to be examined in other cohorts.

\section{Do the findings represent true positive genetic associations?}

It is notable that some of the associations with the strongest statistical support were for associations between a gene and its protein product (e.g. CRP gene and CRP concentration). Cis-acting regulatory variants have been shown to influence mRNA and protein levels for many genes [65]. Studies involving additional biomarker phenotypes and variants (e.g. Affymetrix $500 \mathrm{~K}$ Chip) should clarify whether cis- or trans-acting regulatory variants explain the greatest proportion of phenotypic variation.

With GWAS, which typically test for the association of 1000s of SNPs with multiple traits, it is difficult for any specific association to achieve genome wide significance. For instance, a strict Bonferroni correction for the 30 traits tested in the present study with both age/sex- and multivariable-adjusted models and 2 statistical methods (0.05/ $\left(70,987 * 30^{*} 2 * 2\right)$ would require a $\mathrm{p}=5.9 \times 10^{-9}$. We submit that the most significant association in the selected biomarker group, the FCER1A rs2494250 SNP with MCP1 concentrations achieved genome-wide significance with a GEE $\mathrm{p}=1.0^{*} 10^{-14}$ and a FBAT $\mathrm{p}=3.5^{*} 10^{-8}$. It should be noted that rs 2494250 and rs4128725 are in modest linkage disequilibrium $\left(\mathrm{D}^{\prime}=0.724\right.$ and $\mathrm{r}$ squared $\left.=0.196\right)$ and hence, may be serving as proxies for the same causal SNP.

Several human and experimental studies suggest that the association between FCER1A and MCP1 concentrations is biologically plausible. FCER1A codes for the high affinity Fc receptor fragment for IgE. In vitro experiments with rat mast cells demonstrated that if aggregated the high affinity receptor for IgE (Fc\&RI) increased gene transcription and secretion of MCP1 [66]. Similarly, in mice mast cells if the FceRI was occupied by small amounts IgE/antigen, MCP1 mRNA increased significantly [67]. In humans IgE and MCP1 concentrations are both increased in occupational asthma $[68,69]$. Similar to the animal data, human mast cells exposed to anti-IgE antibody or to IgE released MCP1 [70-72].

\section{Comparison with prior literature}

Our efforts to compare our findings with associations previously reported in the literature underscore some of the challenges in genetic association studies. The ICAM1 gene did not have any markers within $60 \mathrm{~kb}$ on the Affymetrix $100 \mathrm{~K}$ chip. Of the 4 genes that did have SNPs in the marker genomic region coding, only the CRP association was replicated in our cohort; however as noted above we [32], as well as others [20], have previously reported this association. For bilirubin concentrations we previously reported significant linkage to chromosome $2 \mathrm{q}$ telomere [39] and a significant association to a TA repeat in UGT1A1, under this linkage peak [40] in Framingham 
Table 4: Comparison with the prior literature

\begin{tabular}{|c|c|c|c|c|c|c|c|c|c|c|}
\hline Gene & $\begin{array}{c}\text { rs number } \\
\text { previous reports }\end{array}$ & $\begin{array}{l}\text { \# Affy SNPs } \\
\text { within } 60 \mathrm{~kb}\end{array}$ & $\begin{array}{l}\text { rs ID Affy } \\
\text { SNPs }\end{array}$ & Chr & $\mathbf{D}^{\prime}$ & r2 & $\begin{array}{c}\text { Distance } \\
\text { Associated SNP }\end{array}$ & MAF & $\begin{array}{l}\text { FBAT p- } \\
\text { value }\end{array}$ & GEE p-value \\
\hline IL6 & $\begin{array}{l}\mathrm{rs} \mid 800795 \\
=-174 \mathrm{G} / \mathrm{C}\end{array}$ & 7 & rs6461667 & 7 & 1 & 0.82 & 30098 & 0.36 & 0.09 & 0.66 \\
\hline \multirow[t]{5}{*}{ MCPI } & rsl0246II & 13 & rs10491109 & 17 & 1 & 0.04 & 30762 & 0.15 & 0.048 & 0.13 \\
\hline & & & rs 1080327 & & I & 0.96 & 11878 & 0.25 & 0.78 & 0.35 \\
\hline & & & rsl860I8I & & 0.92 & 0.27 & 37799 & 0.45 & 0.04 & 0.11 \\
\hline & & & rsl860I82 & & 0.92 & 0.27 & 37649 & 0.45 & 0.046 & 0.11 \\
\hline & & & rs38I534I & & 1 & 0.02 & 34637 & 0.05 & 0.001 & 0.50 \\
\hline \multirow[t]{20}{*}{ CRP average $2,6,7$} & rsI205 & 37 & rsI446959 & 1 & 0.56 & 0.12 & 75429 & 0.39 & 0.86 & 0.002 \\
\hline & & & rs1891187 & & 0.39 & 0.05 & 53180 & 0.33 & 0.30 & 0.02 \\
\hline & & & rs2808629 & & I & 1 & 5437 & 0.34 & $4.8 * 10^{5}$ & $3.2 * 10^{-8}$ \\
\hline & & & rs2794520 & & 1 & 1 & 3417 & 0.34 & $4.3 * 10^{-5}$ & $2.8^{*} 10^{-8}$ \\
\hline & & & rs4131568 & & 0.63 & 0.12 & 39823 & 0.30 & 0.004 & 0.001 \\
\hline & rs|4I7938 & & rsl446959 & & 0.5 & 0.16 & 77382 & 0.39 & 0.86 & 0.002 \\
\hline & & & rs1891।87 & & 0.29 & 0.07 & 55133 & 0.33 & 0.30 & 0.02 \\
\hline & & & rs2808629 & & I & 0.25 & 7390 & 0.34 & $4.8 * 10^{-5}$ & $3.2 * 10-8$ \\
\hline & & & rs2794520 & & 1 & 0.25 & 5370 & 0.34 & $4.3 * 10^{-5}$ & $2.8^{*} 10^{-8}$ \\
\hline & & & rs4131568 & & 1 & 0.83 & 37870 & 0.30 & 0.004 & 0.001 \\
\hline & & & rs|446959 & & 0.66 & 0.03 & 72832 & 0.39 & 0.86 & 0.002 \\
\hline & rs3093077 & & rs1891।87 & & 0.47 & 0.02 & 50583 & 0.33 & 0.30 & 0.02 \\
\hline & & & rs2808629 & & I & 0.03 & 2840 & 0.34 & $4.8 * 10^{-5}$ & $3.2 * 10-8$ \\
\hline & & & rs2794520 & & I & 0.03 & 820 & 0.34 & $4.3 * 10-5$ & $2.8^{*} 10^{-8}$ \\
\hline & & & rs4131568 & & I & 0.03 & 42420 & 0.30 & 0.004 & 0.001 \\
\hline & & & rs|446959 & & 0.51 & 0.17 & 90106 & 0.39 & 0.86 & 0.002 \\
\hline & rs31I16653 & & rs 1891187 & & 0.31 & 0.08 & 67857 & 0.33 & 0.30 & 0.02 \\
\hline & & & rs2808629 & & 1 & 0.25 & 20114 & 0.34 & $4.8 * 10^{-5}$ & $3.2 * 10-8$ \\
\hline & & & rs2794520 & & 1 & 0.25 & 18094 & 0.34 & $4.3 * 10^{-5}$ & $2.8^{*} 10^{-8}$ \\
\hline & & & rs4131568 & & 1 & 0.83 & 25146 & 0.30 & 0.004 & 0.001 \\
\hline
\end{tabular}

Displayed are SNPs that are either in the highest LD $\left(r^{2}\right)$ with previously reported SNPs or that have an FBAT or GEE $p$-value $<0.05$.

For bilirubin concentrations in Framingham study unrelated participants we previously reported significant linkage to chromosome $2 q$ telomere [39] and a significant association to a TA repeat UGTIAI, there were no association between bilirubin concentrations and I SNP within $30 \mathrm{~kb}$ (rs74I I59) + 2 more SNPs within $50 \mathrm{~kb}$ (rs7260I7 and rs6752792). The previously reported UGTIAI variant is not a SNP and therefore not in HapMap; we have no LD information and cannot assess whether the association previous reported is also present in the current sample. ICAM I on chromosome 19 has 3 reported SNPs in literature (rs I799969, rs549I, rs5498), but there were no Affymetrix SNPs within 60 KB of the gene. CCL2 [Other associated SNPs: rs2857654, rs 1024610, rs2857657 are NOT in HapMap, so no LD information was available.

CRP 2 SNPs are in perfect LD with rs I205. The previously reported triallelic SNP rs309I244 is not in HapMap. CRP association was previously reported in Framingham unrelated participants [32].

unrelated participants. However, there was no association between bilirubin concentrations and the 3 SNP within $60 \mathrm{~kb}$ of UGT1A1. The previously reported interleukin-6IL6 and the MCP1-CCL2 associations were not replicated. Of note, our group previously reported that rs1024611 [in CCL2] was associated with MCP1 concentrations in unrelated participants [63]; the association was nowhere close to significant in the present report (FBAT $\mathrm{p}=0.78$; GEE $\mathrm{p}$ $=0.35$ ) Possible explanations of the failure to confirm the previously reported Framingham study MCP1-CCL2 association may stem from the current report having a smaller sample size ( $n=989)$, using different genetic markers, and being conducted with an additive genetic model in related participants, as opposed to the prior study using unrelated participants $(n=1602)$ with recessive and dominant models. In a recent meta-analysis of phenotype-genotype association studies, only about one third ( 8 of 25) of the associations examined were replicated [73]. There are many plausible explanations why we did not replicate previously reported phenotype-genotype associations. Previous reports could represent false positive findings, or the present and prior study cohorts may differ on key fac- tors, which may modify the phenotype-genotype associations, or our lack of replication may represent a false negative report because of inadequate statistical power $[73,74]$.

\section{Strengths and limitations}

The strengths of the present study include a comprehensively characterized community-based cohort, with biomarker phenotypes routinely assessed with careful attention to quality control. However, the cohort was largely middle-aged to elderly, and white of European descent, so the findings may not be generalizable to individuals who are younger or of other ethnicity/racial descent. DNA was collected at the $5^{\text {th }}$ and $6^{\text {th }}$ examinations, which may have introduced a survival bias. In addition, our study was susceptible to false negative findings because of the moderate size of the cohort; we lacked power to detect modest associations. Conversely, similar to most GWAS, the reported associations and linkage may represent false positive findings from multiple statistical testing. 


\section{Conclusions and future directions}

The Framingham GWAS and the web posting of the unfiltered results represent a unique resource to discover potentially novel genetic influences on systemic biomarker variability. We acknowledge that the newly described associations will need to be replicated in other studies.

\section{Abbreviations}

bp, base pair; Chr, chromosome;CRP, C-reactive protein; FBAT, Family Based Association Tests; GEE, Generalized Estimating Equations; GWAS, Genome-wide association studies; LD, linkage disequilibrium; LOD, logarithm of the odds (base 10); MCP-1, monocyte chemoattractant protein-1; SNPs, single nucleotide polymorphisms.

\section{Competing interests}

The authors declare that they have no competing interests.

\section{Authors' contributions}

EJB conceived of the FHS inflammation project, secured funding, planned the analyses, drafted and critically revised the manuscript. JD assisted in planning and conducting the analyses, and in writing and critically revising the manuscript. MGL planned the FHS inflammation project including assisting in securing funding, and planned and conducted analyses. KLL assisted in planning and conducting the analyses. SLB measured the vitamin data, assisted in planning the analyses and critically revising the manuscript. DRG participated in the study design and reviewed the manuscript. SK contributed to analyses of C-reactive protein and osteoprotegerin, and reviewed the manuscript. JFK assisted in securing the funding, supervised and organized the performance of the assays and reviewed the manuscript. MJK contributed to collecting the data base and revising the manuscript. JPL provided insights into the liver function test analyses and reviewed and approved the manuscript. JBM secured funding for and oversaw measurement of high-sensitivity TNF $\alpha$ concentrations and reviewed and approved the manuscript. SJR contributed to acquisition of the inflammation data, reviewing, revising and giving final approval to the manuscript. JR provided critical assistance in organizing the inflammatory marker data set, conducted quality control analyses and reviewed and gave final approval to the manuscript. RS was involved in revising the manuscript critically for important intellectual content and gave final approval of the version to be published. JAV assisted in securing funding for the inflammation project and revising the manuscript. TJW contributed to the analysis and interpretation of the data, and revision of the manuscript for important intellectual content. PWFW contributed to data acquisition, revision of the manuscript and final approval of the version submitted. PAW participated in $100 \mathrm{~K}$ study design and reviewed and approved the manuscript. RSV provided critical input in conceiving the project, securing the funding, planning the analyses and critically revising the manuscript.

\section{Acknowledgements}

The investigators would like to express their gratitude to the Framingham Heart Study participants and key collaborators: Fox CS, Jacques PF, Lee DS, Lipinska I, Massaro JM, Murabito JM, O'Donnell CJ, Seshadri S, Yang Q. The core examinations were funded by NOI-HC25 195. A portion of the research was conducted using the Boston University Linux Cluster for Genetic Analysis (LinGA) funded by the NIH NCRR (National Center for Research Resources) Shared Instrumentation grant (ISIORRI63736OIAI). Inflammatory markers were measured via HL064753, HL076784, AG02832I (EJB), HL7I 039 (RSV) and 2 K24HL04334 (RSV); osteoprotegerin work was supported by HL064753, HL076784, AG02832 I (EJB) and the Doris Duke Charitable Foundation and NIH IK23 HL083 I02 (SK).

TNF-alpha concentrations were measured via American Diabetes Association Career Development Award and NCRR GCRC M0I-RR-0I066 (JBM); Natriuretic peptides were measured by Shionogi \& Co., Ltd. with an unrestricted research grant; Liver function tests were funded by the core contract; Vitamins were measured by federal funds from the U.S. Department of Agriculture, Agricultural Research Service under Cooperative Agreement No. 58-1950-00 I and No. 58-1950-4-40 I, National Institute of Aging (AGI4759).

This article has been published as part of BMC Medical Genetics Volume 8 Supplement I, 2007: The Framingham Heart Study 100,000 single nucleotide polymorphisms resource. The full contents of the supplement are available online at http://www.biomedcentral.com/I47I-2350/8? issue=SI.

\section{References}

I. Vasan RS: Biomarkers of cardiovascular disease: molecular basis and practical considerations. Circulation 2006, I I 3:2335-2362.

2. Nabel EG: Genomic medicine and cardiovascular disease. Simon Dack Lecture. The American College of Cardiology. [http://www.nhlbi.nih.gov/directorspage/pageimages/03-1I-06acc dack nabel.pdf]. 3-II-2006.

3. Blankenberg S, McQueen MJ, Smieja M, Pogue J, Balion C, Lonn E, Rupprecht HJ, Bickel C, Tiret L, Cambien F, Gerstein H, Munzel T, Yusuf S: Comparative impact of multiple biomarkers and $\mathbf{N}$ Terminal pro-brain natriuretic peptide in the context of conventional risk factors for the prediction of recurrent cardiovascular events in the Heart Outcomes Prevention Evaluation (HOPE) Study. Circulation 2006, I | 4:20I-208.

4. Kistorp C, Raymond I, Pedersen F, Gustafsson F, Faber J, Hildebrandt $\mathrm{P}$ : N-terminal pro-brain natriuretic peptide, C-reactive protein, and urinary albumin levels as predictors of mortality and cardiovascular events in older adults. JAMA 2005, 293:1609-1616.

5. Wang TJ, Larson MG, Levy D, Benjamin EJ, Leip EP, Omland T, Wolf PA, Vasan RS: Plasma natriuretic peptide levels and the risk of cardiovascular events and death. N Engl J Med 2004, 350:655-663.

6. Wannamethee G, Ebrahim S, Shaper AG: Gamma-glutamyltransferase: determinants and association with mortality from ischemic heart disease and all causes. Am J Epidemiol 1995, I 42:699-708.

7. Lee DS, Evans JC, Robins SJ, Wilson PW, Albano I, Fox CS, Wang TJ, Benjamin EJ, D'Agostino RB, Vasan RS: Gamma glutamyl transferase and metabolic syndrome, cardiovascular disease, and mortality risk: the Framingham Heart Study. Arterioscler Thromb Vasc Biol 2007, 27: 127-133.

8. Scragg R, Jackson R, Holdaway IM, Lim T, Beaglehole R: Myocardial infarction is inversely associated with plasma 25 -hydroxyvitamin D3 levels: a community-based study. Int J Epidemiol 1990, 19:559-563.

9. Ridker PM, Hennekens $\mathrm{CH}$, Buring JE, Rifai N: C-reactive protein and other markers of inflammation in the prediction of cardiovascular disease in women. N Engl J Med 2000, 342:836-843. 
10. Danesh J, Collins R, Appleby P, Peto R: Association of fibrinogen, C-reactive protein, albumin, or leukocyte count with coronary heart disease: meta-analyses of prospective studies. JAMA 1998, 279: |477-| 482.

II. Kuller LH, Tracy RP, Shaten J, Meilahn EN, the MRFIT Research Group: Relation of C-reactive protein and coronary heart disease in the MRFIT nested case-control study. Am J Epidemio 1996, I 44:537-547.

12. Ridker PM, Hennekens CH, Roitman-Johnson B, Stampfer MJ, Allen J: Plasma concentration of soluble intercellular adhesion molecule $I$ and risks of future myocardial infarction in apparently healthy men. Lancet 1998, 35 I:88-92.

13. Harris TB, Ferrucci L, Tracy RP, Corti MC, Wacholder S, Ettinger WH Jr, Heimovitz H, Cohen HJ, Wallace R: Associations of elevated interleukin-6 and C-reactive protein levels with mortality in the elderly. Am J Med 1999, 106:506-5I2.

14. Dupuis J, Larson MG, Vasan RS, Massaro JM, Wilson PW, Lipinska I, Corey D, Vita JA, Keaney JF Jr, Benjamin E): Genome scan of systemic biomarkers of vascular inflammation in the Framingham Heart Study: evidence for susceptibility loci on Iq. Atherosclerosis 2005, | 82:307-3/4.

15. Pankow JS, Folsom AR, Cushman M, Borecki IB, Hopkins PN, Eckfeldt $\mathrm{H}$, Tracy RP: Familial and genetic determinants of systemic markers of inflammation: the NHLBI family heart study. Atherosclerosis 200I, I 54:68I-689.

16. Wang TJ, Larson MG, Levy D, Benjamin EJ, Corey D, Leip EP, Vasan RS: Heritability and genetic linkage of plasma natriuretic peptide levels. Circulation 2003, 108:13-16.

17. Bathum L, Petersen HC, Rosholm JU, Hyltoft PP, Vaupel J, Christensen K: Evidence for a substantial genetic influence on biochemical liver function tests: results from a populationbased Danish twin study. Clin Chem 200I, 47:8I-87.

18. Pilia G, Chen WM, Scuteri A, Orru M, Albai G, Dei M, Lai S, Usala G, Lai M, Loi P, Mameli C, Vacca L, Deiana M, Olla N, Masala M, Cao A, Najjar SS, Terracciano A, Nedorezov T, Sharov A, Zonderman AB, Abecasis GR, Costa P, Lakatta E, Schlessinger D: Heritability of cardiovascular and personality traits in 6,148 Sardinians. PLoS Genet 2006, 2:el32.

19. Hunter D, De Lange M, Snieder H, MacGregor AJ, Swaminathan R, Thakker RV, Spector TD: Genetic contribution to bone metabolism, calcium excretion, and vitamin $D$ and parathyroid hormone regulation. J Bone Miner Res 200I, 16:37|-378.

20. Carlson CS, Aldred SF, Lee PK, Tracy RP, Schwartz SM, Rieder M, Liu $\mathrm{K}$, Williams OD, Iribarren C, Lewis EC, Fornage M, Boerwinkle E, Gross M, Jaquish C, Nickerson DA, Myers RM, Siscovick DS, Reiner AP: Polymorphisms within the C-reactive protein (CRP) promoter region are associated with plasma CRP levels. Am Hum Genet 2005, 77:64-77.

21. Cupples LA, Arruda HT, Benjamin EJ, D'Agostino RB Sr, Demissie S, DeStefano AL, Dupuis J, Falls K, Fox CS, Gottlieb DJ, Govindaraju DR, Guo CY, Heard-Costa NL, Hwang SJ, Kathiresan S, Kiel DP, Laramie JM, Larson MG, Levy D, Liu CY, Lunetta KL, Mailman MD, Manning AK, Meigs JB, Murabito JM, Newton-Cheh C, O'Connor GT, O'Donnell CJ, Pandey MA, Seshadri S, Vasan RS, Wang ZY, Wilk JB, Wolf PA, Yang Q, Atwood LD: The Framingham Heart Study I00K SNP genome-wide association study resource: Overview of 17 phenotype working group reports. BMC Med Genet 2007, 8(Suppl I):SI.

22. Kannel WB, Feinleib M, McNamara PM, Garrison RJ, Castelli WP: An investigation of coronary heart disease in families. The Framingham offspring study. Am J Epidemiol 1979, I 1 0:281-290.

23. Vasan RS, Benjamin EJ, Larson MG, Leip EP, Wang TJ, Wilson PW, Levy D: Plasma natriuretic peptides for community screening for left ventricular hypertrophy and systolic dysfunction: the Framingham heart study. JAMA 2002, 288: I252-I259.

24. Walters MI, Gerarde HW: A microspectrophotometric method for the determination of bilirubin. Microchemical J 1968 13:253-272.

25. Djousse L, Levy D, Cupples LA, Evans JC, D'Agostino RB, Ellison RC Total serum bilirubin and risk of cardiovascular disease in the Framingham offspring study. Am J Cardiol 200I, 87:1196-1200

26. Roy AV: Rapid method for determining alkaline phosphatase activity in serum with thymolphthalein monophosphate. Clin Chem 1970, 16:431-436.
27. Proksch G], Bonderman DP, Griep JA: AutoAnalyzer assay for serum alkaline phosphatase activity, with sodium thymolphthalein monophosphate as substrate. Clin Chem 1973, 19:103-105.

28. Henry RJ, Chiamori N, Golub OJ, Berkman S: Revised spectrophotometric methods for the determination of glutamic-oxalacetic transaminase, glutamic-pyruvic transaminase, and lactic acid dehydrogenase. Am J Clin Pathol 1960, 34:381-398.

29. Davidson KW, Sadowski JA: Determination of vitamin K compounds in plasma or serum by high-performance liquid chromatography using postcolumn chemical reduction and fluorimetric detection. Methods Enzymol 1997, 282:408-421.

30. Gundberg CM, Hauschka PV, Lian JB, Gallop PM: Osteocalcin: isolation, characterization, and detection. Methods Enzymol 1984, 107:5। 6-544.

31. Gundberg CM, Nieman SD, Abrams S, Rosen H: Vitamin K status and bone health: an analysis of methods for determination of undercarboxylated osteocalcin. I Clin Endocrinol Metab 1998 83:3258-3266.

32. Kathiresan S, Larson MG, Vasan RS, Guo CY, Gona P, Keaney JF Jr, Wilson PW, Newton-Cheh C, Musone SL, Camargo AL, Drake JA, Levy D, O'Donnell CJ, Hirschhorn JN, Benjamin EJ: Contribution of clinical correlates and I 3 C-reactive protein gene polymorphisms to interindividual variability in serum C-reactive protein level. Circulation 2006, I I3:|4| 5- |423.

33. Herbert A, Gerry NP, McQueen MB, Heid IM, Pfeufer A, Illig T, Wichmann HE, Meitinger T, Hunter D, Hu FB, Colditz G, Hinney A, Hebebrand J, Koberwitz K, Zhu X, Cooper R, Ardlie K, Lyon H, Hirschhorn JN, Laird NM, Lenburg ME, Lange C, Christman MF: A common genetic variant is associated with adult and childhood obesity. Science 2006, 3 I 2:279-283.

34. Abecasis GR, Cherny SS, Cookson WO, Cardon LR: Merlin - rapid analysis of dense genetic maps using sparse gene flow trees. Nat Genet 2002, 30:97-101.

35. Almasy L, Blangero J: Multipoint quantitative-trait linkage analysis in general pedigrees. Am J Hum Genet 1998, 62:1198-1211.

36. Nagelkerke NJD: A note on a general definition of the coefficient of determination. Biometrika |99|, 78:69|-692.

37. Cockayne S, Adamson J, Lanham-New S, Shearer MJ, Gilbody S, Torgerson DJ: Vitamin $\mathbf{K}$ and the prevention of fractures: systematic review and meta-analysis of randomized controlled trials. Arch Intern Med 2006, 166:1256-126I.

38. Szulc P, Chapuy MC, Meunier PJ, Delmas PD: Serum undercarboxylated osteocalcin is a marker of the risk of hip fracture in elderly women. J Clin Invest 1993, 91:1769-1774.

39. Lin JP, Cupples LA, Wilson PW, Heard-Costa N, O'Donnell CJ: Evidence for a gene influencing serum bilirubin on chromosome 2q telomere: a genomewide scan in the Framingham study. Am J Hum Genet 2003, 72:1029-1034.

40. Lin JP, O'Donnell CJ, Schwaiger JP, Cupples LA, Lingenhel A, Hunt SC Yang S, Kronenberg F: Association between the UGTIAI*28 allele, bilirubin levels, and coronary heart disease in the Framingham Heart Study. Circulation 2006, I | 4: |476-|48|

4I. Zee RY, Ridker PM: Polymorphism in the human C-reactive protein (CRP) gene, plasma concentrations of CRP, and the risk of future arterial thrombosis. Atherosclerosis 2002, 162:217-219.

42. Szalai AJ, McCrory MA, Cooper GS, Wu J, Kimberly RP: Association between baseline levels of $C$-reactive protein (CRP) and a dinucleotide repeat polymorphism in the intron of the CRP gene. Genes Immun 2002, 3:14-19.

43. Suk HJ, Ridker PM, Cook NR, Zee RY: Relation of polymorphism within the C-reactive protein gene and plasma CRP levels. Atherosclerosis 2005, I 78: 139-। 45.

44. Davey SG, Lawlor DA, Harbord R, Timpson N, Rumley A, Lowe GD, Day IN, Ebrahim S: Association of C-reactive protein with blood pressure and hypertension: life course confounding and mendelian randomization tests of causality. Arterioscler Thromb Vasc Biol 2005, 25: 105I-1056.

45. Balistreri CR, Vasto S, Listi F, Grimaldi MP, Lio D, Colonna-Romano G, Caruso M, Caimi G, Hoffmann E, Caruso C, Candore G: Association between +1059G/C CRP polymorphism and acute myocardial infarction in a cohort of patients from Sicily: a pilot study. Ann N Y Acad Sci 2006, 1067:276-28I.

46. Miller DT, Zee RY, Suk DJ, Kozlowski P, Chasman DI, Lazarus R, Cook NR, Ridker PM, Kwiatkowski DJ: Association of Common 
CRP Gene Variants with CRP Levels and Cardiovascular Events. Ann Hum Genet 2005, 69:623-638.

47. Eklund C, Lehtimaki T, Hurme M: Epistatic effect of C-reactive protein (CRP) single nucleotide polymorphism (SNP) + 1059 and interleukin-IB SNP +3954 on CRP concentration in healthy male blood donors. Int I Immunogenet 2005, 32:229-232.

48. Szalai AJ, Wu J, Lange EM, McCrory MA, Langefeld CD, Williams A, Zakharkin SO, George V, Allison DB, Cooper GS, Xie F, Fan Z, Edberg JC, Kimberly RP: Single-nucleotide polymorphisms in the C-reactive protein (CRP) gene promoter that affect transcription factor binding, alter transcriptional activity, and associate with differences in baseline serum CRP level. Mol Med 2005, 83:440-447.

49. D'Aiuto F, Casas JP, Shah T, Humphries SE, Hingorani AD, Tonetti MS: C-reactive protein $(+\mid 444 C>T)$ polymorphism influences CRP response following a moderate inflammatory stimulus. Atherosclerosis 2005, 179:413-4I7.

50. Kovacs A, Green F, Hansson LO, Lundman P, Samnegard A, Boquist S, Ericsson CG, Watkins H, Hamsten A, Tornvall P: A novel common single nucleotide polymorphism in the promoter region of the C-reactive protein gene associated with the plasma concentration of C-reactive protein. Atherosclerosis 2005, I 78: 193-198.

51. Register TC, Burdon KP, Lenchik L, Bowden DW, Hawkins GA, Nicklas BJ, Lohman K, Hsu FC, Langefeld CD, Carr JJ: Variability of serum soluble intercellular adhesion molecule-I measurements attributable to a common polymorphism. Clin Chem 2004, 50:2185-2।87.

52. Puthothu B, Krueger M, Bernhardt M, Heinzmann A: ICAMI aminoacid variant $\mathrm{K} 469 \mathrm{E}$ is associated with paediatric bronchial asthma and elevated sICAMI levels. Genes Immun 2006 7:322-326.

53. Kronig H, Riedel M, Schwarz MJ, Strassnig M, Moller HJ, Ackenheil M, Muller N: ICAM G24IA polymorphism and soluble ICAM-I serum levels: evidence for an active immune process in schizophrenia. Neuroimmunomodulation 2005, 12:54-59.

54. Ponthieux A, Lambert D, Herbeth B, Droesch S, Pfister M, Visvikis S: Association between Gly24IArg ICAM-I gene polymorphism and serum sICAM-I concentration in the Stanislas cohort. Eur J Hum Genet 2003, I I:679-686.

55. Brull DJ, Montgomery HE, Sanders J, Dhamrait S, Luong L, Rumley A, Lowe GD, Humphries SE: Interleukin-6 gene $-174 \mathrm{~g}>\mathrm{c}$ and $572 \mathrm{~g}>\mathrm{c}$ promoter polymorphisms are strong predictors of plasma interleukin-6 levels after coronary artery bypass surgery. Arterioscler Thromb Vasc Biol 200 I, 21:|458-| 463.

56. Boiardi L, Casali B, Farnetti E, Pipitone N, Nicoli D, Cantini F, Macchioni P, Bajocchi G, Catanoso MG, Pulsatelli L, Consonni D, Salvarani C: Relationship between interleukin 6 promoter polymorphism at position -174, IL-6 serum levels, and the risk of relapse/recurrence in polymyalgia rheumatica. J Rheumatol 2006, 33:703-708.

57. Liu Y, Berthier-Schaad Y, Fallin MD, Fink NE, Tracy RP, Klag MJ, Smith MW, Coresh J: IL-6 haplotypes, inflammation, and risk for cardiovascular disease in a multiethnic dialysis cohort. J Am Soc Nephrol 2006, 17:863-870

58. Libra M, Signorelli SS, Bevelacqua $Y$, Navolanic PM, Bevelacqua $V$, Polesel J, Talamini R, Stivala F, Mazzarino MC, Malaponte G: Analysis of G(-174)C IL-6 polymorphism and plasma concentrations of inflammatory markers in patients with type 2 diabetes and peripheral arterial disease. J Clin Pathol 2006, 59:2 III-2I5.

59. Ravaglia G, Forti P, Maioli F, Chiappelli M, Dolzani P, Martelli M, Bianchin M, Mariani E, Bolondi L, Licastro F: Associations of the 174 G/C interleukin-6 gene promoter polymorphism with serum interleukin 6 and mortality in the elderly. Biogerontology 2005, 6:415-423.

60. Cardellini M, Perego L, D'Adamo M, Marini MA, Procopio C, Hribal ML, Andreozzi F, Frontoni S, Giacomelli M, Paganelli M, Pontiroli AE, Lauro R, Folli F, Sesti G: C-I 74G polymorphism in the promoter of the interleukin-6 gene is associated with insulin resistance. Diabetes Care 2005, 28:2007-20I2.

6I. Barbieri M, Rizzo MR, Papa M, Acampora R, De Angelis L, Olivieri F, Marchegiani F, Franceschi C, Paolisso G: Role of interaction between variants in the PPARG and interleukin- 6 genes on obesity related metabolic risk factors. Exp Gerontol 2005, 40:599-604.
62. Haddy N, Sass C, Maumus S, Marie B, Droesch S, Siest G, Lambert D, Visvikis $S$ : Biological variations, genetic polymorphisms and familial resemblance of TNF-alpha and IL-6 concentrations: STANISLAS cohort. Eur J Hum Genet 2005, I 3: 109-I I7.

63. McDermott DH, Yang Q, Kathiresan S, Cupples LA, Massaro JM, Keaney JF Jr, Larson MG, Vasan RS, Hirschhorn JN, O'Donnell CJ, Murphy PM, Benjamin E): CCL2 polymorphisms are associated with serum monocyte chemoattractant protein-I levels and myocardial infarction in the Framingham Heart Study. Circulation 2005, I | 2: I I I3- I I 20.

64. Joven J, Coll B, Tous M, Ferre N, Alonso-Villaverde C, Parra S, Camps J: The influence of HIV infection on the correlation between plasma concentrations of monocyte chemoattractant protein-I and carotid atherosclerosis. Clin Chim Acta 2006, 368:114-119.

65. Cheung VG, Spielman RS, Ewens KG, Weber TM, Morley M, Burdick $\mathrm{JT}$ : Mapping determinants of human gene expression by regional and genome-wide association. Nature 2005, 437:1365-1369.

66. Eglite S, Morin JM, Metzger H: Synthesis and secretion of monocyte chemotactic protein-I stimulated by the high affinity receptor for IgE. J Immunol 2003, I70:2680-2687.

67. Gonzalez-Espinosa C Odom S, Olivera A, Hobson JP, Martinez ME Oliveira-Dos-Santos A, Barra L, Spiegel S, Penninger JM, Rivera J: Preferential signaling and induction of allergy-promoting lymphokines upon weak stimulation of the high affinity IgE receptor on mast cells. J Exp Med 2003, 197: | 453-| 465

68. Malo JL, L'Archeveque J, Lummus Z, Bernstein D: Changes in specific IgE and IgG and monocyte chemoattractant protein-I in workers with occupational asthma caused by diisocyanates and removed from exposure. I Allergy Clin Immunol 2006, I I 8:530-533.

69. Bernstein DI, Cartier A, Cote J, Malo JL, Boulet LP, Wanner M, Milot J. L'Archeveque J, Trudeau C, Lummus Z: Diisocyanate antigenstimulated monocyte chemoattractant protein-I synthesis has greater test efficiency than specific antibodies for identification of diisocyanate asthma. Am J Respir Crit Care Med 2002, 166:445-450.

70. Baghestanian M, Hofbauer R, Kiener HP, Bankl HC, Wimazal F, Willheim M, Scheiner O, Fureder W, Muller MR, Bevec D, Lechner K, Valent P: The c-kit ligand stem cell factor and anti-IgE promote expression of monocyte chemoattractant protein-I in human lung mast cells. Blood 1997, 90:4438-4449.

71. Matsuda K, Piliponsky AM, likura M, Nakae S, Wang EW, Dutta SM, Kawakami T, Tsai M, Galli SJ: Monomeric IgE enhances human mast cell chemokine production: IL-4 augments and dexamethasone suppresses the response. J Allergy Clin Immunol 2005, I 16:1357-1363.

72. Gosset P, Tillie-Leblond I, Oudin S, Parmentier O, Wallaert B, Joseph $M$, Tonnel $A B$ : Production of chemokines and proinflammatory and antiinflammatory cytokines by human alveolar macrophages activated by IgE receptors. J Allergy Clin Immunol 1999, 103:289-297.

73. Lohmueller KE, Pearce CL, Pike M, Lander ES, Hirschhorn JN: Metaanalysis of genetic association studies supports a contribution of common variants to susceptibility to common disease. Nat Genet 2003, 33:177-182.

74. Hegele RA: SNP judgments and freedom of association. Arterioscler Thromb Vasc Biol 2002, 22:1058-106I. 